ROBERT ZIOLKOWSKI, Ph.D.

E-mail: robert.ziolkowski@pb.edu.pl

Bialystok University of Technology

Faculty of Civil and Environmental Engineering

Wiejska 45E, 15-351 Bialystok, Poland
Traffic Engineering

Preliminary Communication

Submitted: 19 Aug. 2018

Accepted: 5 Apr. 2019

\title{
EFFECTIVENESS OF AUTOMATIC SECTION SPEED CONTROL SYSTEM OPERATING ON NATIONAL ROADS IN POLAND
}

\begin{abstract}
Driving speed remains within the most important factors in road safety, and speed not only affects the severity of a crash but is also related to the risk of being involved in a crash. Inappropriate speed is responsible for more than a third of all fatal accidents occurring on roads. In Poland the problem of speeding drivers is widely present. Hence, effective speed management and enforcement of speed limits on existing roads plays an important role. Possible solutions for rural roads are very limited and are focused mainly on administrative speed limitations and speed cameras enforcement. However, due to their limited effectiveness new solutions are still being sought. High expectations are associated with the automatic section speed control system that has recently been introduced in Poland. The aim of this paper is to examine the efficiency of the automatic section speed control system on the basis of speed surveys collected on chosen national roads where the system for sectional speed control was first implemented. Conducted comparisons and statistical analyses included driver's average speed, speed percentiles, the number of speeding drivers as well as speed heterogeneity. To evaluate the efficacy of the sectional speed system, speed measurements were also conducted on fourteen, similar in geometry and functional characteristics, reference national roads located in Podlaskie voivodship in Poland without any specific speed enforcement.
\end{abstract}

\section{KEY WORDS}

traffic management; section speed control; excessive speed; heterogeneity of speed;

\section{INTRODUCTION}

Driving speed remains one of the most important factors in road safety, and speed not only affects the severity of a crash but is also related to the risk of being involved in a crash [1-4]. According to the International Transport Forum [5], unadjusted and excessive speed is the main cause of one third of all fatal road crashes e.g. in Ireland, Hungary, Poland, Lithuania. The same conclusions emerge from official statistics published yearly in Poland by the Police Headquarters [6]. Additionally, higher speed involves higher risk of accident and possible consequences. Lots of attention is given to an effective speed reduction as 5\% reduction in speed leads to $10 \%$ reduction in accidents causing injuries, 15\% reduction in accidents causing serious injuries and $20 \%$ reduction in accidents involving fatalities (Figure 1). In Poland the consideration of the driver's speed focuses mainly on instantaneous speed investigations conducted on national roads which are characterised by the highest number of deaths and severe injuries [7-9]. During the last two decades a number of activities and campaigns towards the improvement of safety conditions on roads in Poland have been undertaken. Those included among the others include: renovations of vertical and horizontal markings, black spots, speed cameras, road rebuilding, TV and radio campaigns against speeding and drug driving. However, their results were not satisfied or their effectiveness was limited and hence, new solutions are still being sought. Since 2011 the Centre for Automated Traffic Surveillance (CANARD) started to operate. Its main objective is prevention of the greatest threat on roads - over-speeding. In 2016 they finalised, supported by EU funds, the installation of automatic section speed control system that includes 30 sections located on national roads in Poland. Similar systems already operate in Europe bringing positive effects in safety statistics. In the Netherlands and Austria the number of fatalities and serious accidents was reduced by more than 50\%. In Italy the effects showed a reduction of $15 \%$ in average speeds, $51 \%$ in the

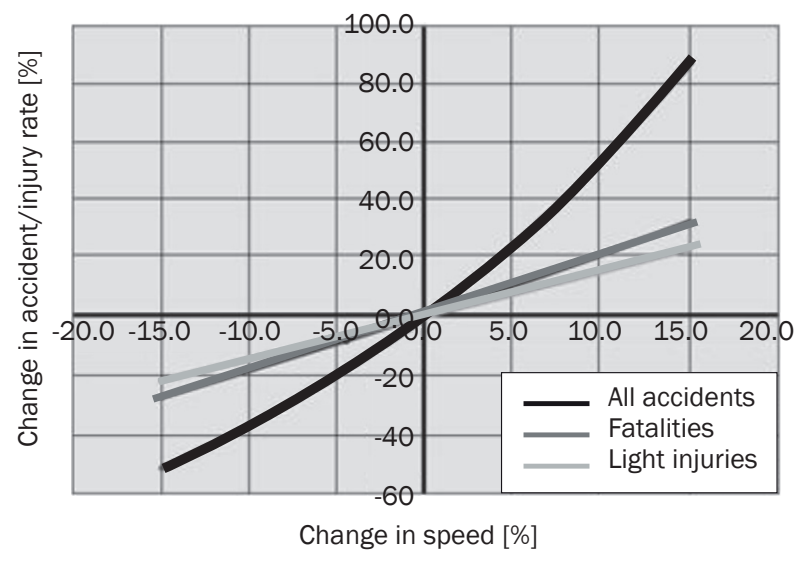

Figure 1 - The Power model of the relationship between speed and road safety [2] 
number of fatalities and $27 \%$ in the number of the injured. In Norway the reduction of $12 \%$ for injury crashes was insignificant, but the number of killed or severely injured was significantly reduced by $49 \%$ [10-13].

Investigations conducted for this study focused on sectional speed measurements conducted on several sections of national roads in Poland which were first equipped with an automatic section speed control system (ASSC). Investigations included roads where the system has been in operation for at least 12 months, so that the drivers were already familiar with its presence.

The main objective of this study paper was to examine the efficiency of the automatic section speed control system in rural and built-up areas. The assessment was conducted in terms of its influence on changes of main speed parameters e.g. average speed, speed percentiles, percent of speeding drivers and speed homogeneity. The speed data were recorded on road sections with the speed control system and for comparative analysis on other, similar in geometry characteristics, national roads located in Podlaskie voivodship in Poland.

\section{RESEARCH AREA AND SPEED ACQUISITION}

Research area included 22 sections of national roads - eight of them under the surveillance of the automatic section speed control system (Figure 2a) and another 14 sections were chosen on national roads running through Podlaskie province and constituting the reference sections in later comparisons (Figure 2b). In case of automatic section speed control system, sections of the speed data were gained from the operator of the system (CANARD - Center for Automatic Control of Traffic). Speed measurements on those sections were performed with the use of a set of two ANPR (Automatic Number Plate Recognition) cameras installed on the check points. Vehicles passing through the check points located at the beginning and end point of every controlled section were detected and recorded by video-cameras. Each camera read the vehicle number plate and encrypted it using the cryptology methods. When the vehicle exits the section the number plate is again read and matched to the plate captured at the beginning of the section. Using these two data records and the elapsed time between them, the system calculated the average speed based on the length of the section. To evaluate the effectiveness of the ASSC system for comparative analyses 14 road sections without any but administrative speed restrictions were chosen. Those sections included six rural road segments with $90 \mathrm{~km} / \mathrm{h}$ speed limit and eight segments in built-up areas: two segments with a $70 \mathrm{~km} / \mathrm{h}$ speed limit and six segments with $50 \mathrm{~km} / \mathrm{h}$ speed limit. The chosen roads are national ones with prevailing long distance travellers so it is believed that such conditions would prevent a situation where local habits could interfere with results. All investigated

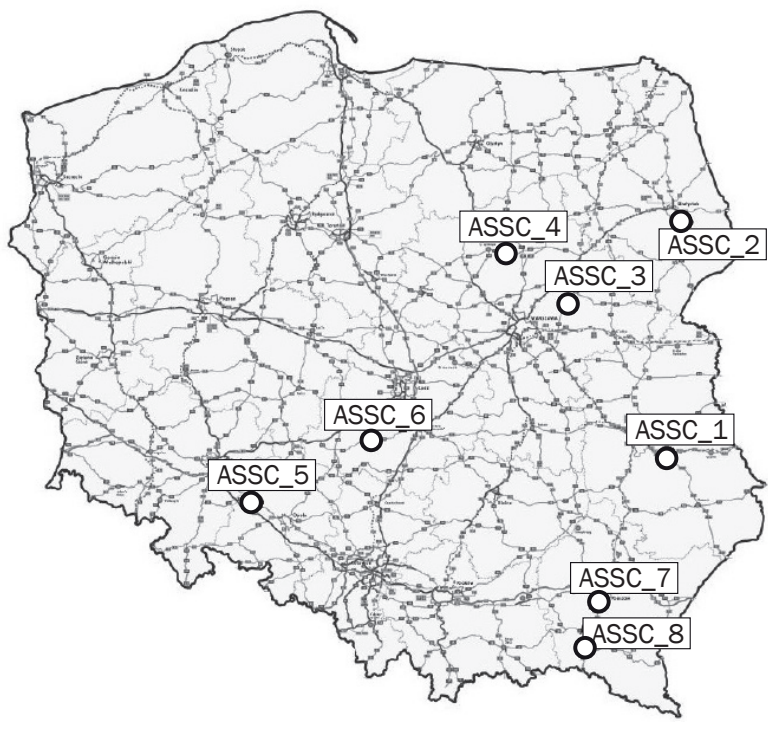

a) ASSC sections

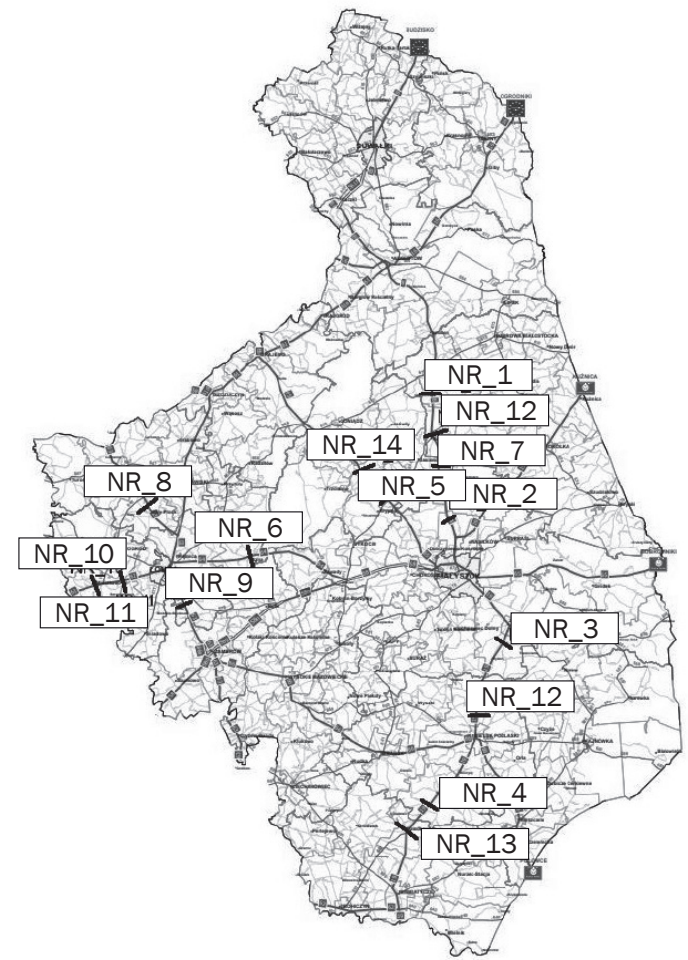

b) Measurement points on reference national roads in Podlaskie province

Figure 2 - Speed measurement sites 
roads are single carriageway, two-directional roads. To perform section speed measurements on those segments a set of two ANPR cameras was used and measurements were accomplished within one month with an average number of 400 vehicles recorded.

\section{DATA ANALYSES}

\subsection{Speed measurements on reference national roads in Podlaskie voivedeship}

Average speed values collected during the measurements and basic speed parameters are presented in Table 1. The administrative speed limit for those sections was $90 \mathrm{~km} / \mathrm{h}$ on rural roads and $70 \mathrm{~km} / \mathrm{h}$ or $50 \mathrm{~km} / \mathrm{h}$ in the built-up areas. As a general conclusion arising from the presented data it can be seen that lots of drivers did not adjust their driving speed to the existing speed limit especially in the built-up areas. In each case, except of road section NR_7 and NR_13, the average speed was above the existing limit.

The data presented in Table 1 reveal that the majority of drivers in built-up areas exceed the posted speed limits, and so the efficiency of administrative speed limit as a basic tool to control speed is very limited and obviously unsatisfactory. It results from the achieved data that the lowered speed limits in urban areas push more drivers to violate traffic regulations. The highest percent of drivers who exceeded the posted speed limitation (78.2\%) was recorded on road section NR_14 in built-up area where the speed limit was lowered to 50 $\mathrm{km} / \mathrm{h}$. On the other hand, the best results, reflecting the driver's behaviour in terms of adhering to traffic rules, were found on road section NR_10 where only $11.1 \%$ of drivers did not comply with the relevant provisions. Generally, a large number of speeding drivers confirms the necessity for the implementation of more effective solutions of speed management because administrative speed limits are not very powerful as one of the basic measures being applied. Their effectiveness, based on the results presented in Table 1, is highly questionable.

The average speed recorded on six rural roads with $90 \mathrm{~km} / \mathrm{h}$ speed limit was $86.4 \mathrm{~km} / \mathrm{h}$ and the difference between the highest and the lowest average speed value was $13.9 \%$. Even more distinct differences can be observed in terms of $85^{\text {th }}$ and $15^{\text {th }}$ percentile. The difference between these parameters related to the average speed can be used to evaluate the heterogeneity of speed $\left(S_{H}\right)$. The highest and the lowest SH values were achieved for road sections NR_6 and NR_3 $\left(S_{H}=22.2 \%\right.$ and $S_{H}=11.8 \%$, respectively).

In case of national road sections in built-up areas with implemented local $50 \mathrm{~km} / \mathrm{h}$ speed limits the average speed was $55.3 \mathrm{~km} / \mathrm{h}$ and the difference in average speed between the highest (NR_14) and the lowest (NR_13) section was 31.8\%. High heterogeneity of speed is confirmed by calculated extreme $S_{H}$ values: the highest $S_{H}=45.8 \%$ for NR_14 and the lowest $S_{H}=$ 27.4 for NR_13 which are distinctly higher when compared to extreme $S_{H}$ values of rural roads. $S_{H}$ values for road sections in built-up areas with $70 \mathrm{~km} / \mathrm{h}$ speed limit are $34.6 \%$ and $18.9 \%$, respectively, and also reflect high speed heterogeneity.

To verify statistically the essential differences between average speeds, the variance analysis was conducted. Figure 3 presents the plot of average speed values with 95\% confidence interval for each referenced road section and Figures $4 a$ and $4 b$ show the average speed values with calculated standard deviation (SD) for roads with $50 \mathrm{~km} / \mathrm{h}$ and $90 \mathrm{~km} / \mathrm{h}$ speed limits. The ANOVA analysis has confirmed the existence of significant differences between the average speeds on investigated roads $(p=.1739)$.

Table 1 - Characteristic of speed parameters observed on national roads in Podlaskie voivodeship

\begin{tabular}{|c|c|c|c|c|c|c|c||}
\hline \hline Road No. & $\begin{array}{c}\text { Length of the } \\
\text { section }[\mathrm{m}]\end{array}$ & $\begin{array}{c}\text { Speed limit } \\
{[\mathrm{km}]}\end{array}$ & $\begin{array}{c}\text { Average speed } \\
V_{a v g}[\mathrm{~km} / \mathrm{h}]\end{array}$ & $\begin{array}{c}85^{\text {th }} \text { percentile } \\
\text { V85 }[\mathrm{km} / \mathrm{h}]\end{array}$ & $\begin{array}{c}15^{\text {th }} \text { percentile } \\
\text { V15 }[\mathrm{km} / \mathrm{h}]\end{array}$ & $P_{s p}[\%]$ & SD \\
\hline \hline NR_1 & 6,600 & 90 & 81.3 & 87.7 & 75.0 & 11.5 & 7.4 \\
\hline NR_2 & 8,000 & 90 & 84.4 & 93.7 & 76.6 & 21.4 & 8.2 \\
\hline NR_3 & 5,600 & 90 & 82.5 & 80.7 & 71.0 & 24.2 & 11.2 \\
\hline NR_4 & 6,000 & 90 & 88.2 & 87.3 & 76.0 & 29.0 & 14.0 \\
\hline NR_5 & 6,300 & 90 & 92.6 & 100.7 & 84.0 & 53.4 & 10.6 \\
\hline NR_6 & 5,700 & 90 & 89.5 & 95.6 & 75.7 & 43.9 & 12.1 \\
\hline NR_7 & 5,000 & 70 & 68.6 & 75.0 & 62.0 & 27.8 & 7.9 \\
\hline NR_8 & 4,900 & 70 & 75.2 & 89.0 & 63.0 & 55.2 & 12.1 \\
\hline NR_9 & 4,500 & 50 & 55.3 & 63.0 & 49.0 & 23.2 & 8.1 \\
\hline NR_10 & 3,800 & 50 & 53.7 & 60.0 & 40.0 & 11.1 & 7.2 \\
\hline NR_11 & 6,100 & 50 & 57.4 & 67.7 & 47.1 & 67.6 & 9.7 \\
\hline NR_12 & 5,300 & 50 & 55.4 & 65.0 & 47.0 & 64.5 & 9.6 \\
\hline NR_13 & 7,300 & 50 & 47.4 & 55.0 & 42.0 & 36.7 & 6.2 \\
\hline NR_14 & 5,000 & 50 & 62.5 & 76.4 & 47.8 & 78.2 & 14.4 \\
\hline
\end{tabular}

$P_{s p}$ - percentage of speeding drivers 


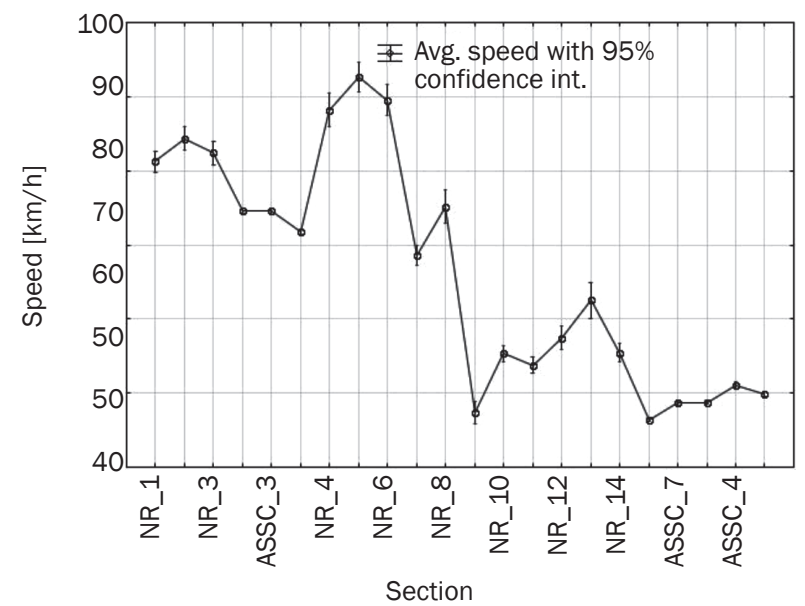

Figure 3 - Plot of average speed values with 95\% confidence interval on investigated road sections

Further variance analysis conducted for roads separated due to speed limits also revealed statistically significant differences between average speed values $(p=.0000)$.

\subsection{Speed data collected on roads with ASSC}

Speed data recorded on roads with automatic section speed control system are presented in Table 2. Three out of eight sections are located in rural areas

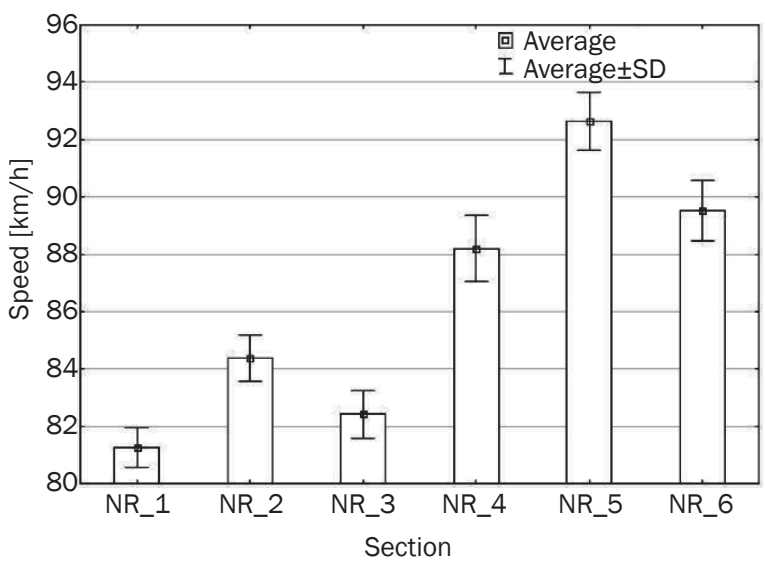

a) Sections with $90 \mathrm{~km} / \mathrm{h}$ speed limit with speed limit of $90 \mathrm{~km} / \mathrm{h}$ while the other five are through roads in built-up areas with a speed limit of $50 \mathrm{~km} / \mathrm{h}$.

Data shown in Table 2 reveal that most of all sectional speed control systems is highly effective especially in terms of average speeds. On rural roads in each case the average speed was much below the speed limit and the highest value $\left(V_{a v g}=75.7 \mathrm{~km} / \mathrm{h}\right)$ recorded on the ASSC_2 section was 15.9\% lower than the existing speed limit. In case of sections located in urban areas, except ASSC_4 and ASSC_8 sections $\left(V_{a v g}=51.8 \mathrm{~km} / \mathrm{h}\right.$ and $V_{\text {avg }}=50.0 \mathrm{~km} / \mathrm{h}$, respectively) the average speed values did not exceed the existing speed limit. However, considering the numbers of speeding drivers the efficiency of sectional speed control system brings much better effect on rural roads than on roads within urban areas. The highest percentage of speeding drivers was recorded on ASSC_3 section and accounted for by less than $2.8 \%$ of all drivers. Analysing the speeding drivers recorded in built-up areas the highest percent of disobeying drivers (52.9\%) was recorded on ASSC_4 section while the lowest percentage was recorded on ASSC_5 section (13.3\%). Also, the analysis of speed heterogeneity showed higher speed variety on roads in urban areas. The highest $\mathrm{SH}$ value calculated for roads with a $50 \mathrm{~km} / \mathrm{h}$ speed limit $\left(S_{H}=23 \%\right.$, ASSC_4) is

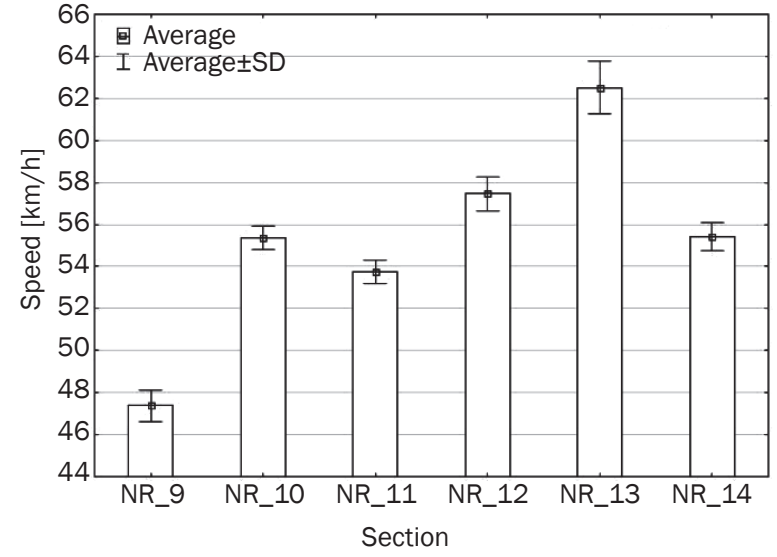

b) Sections with $50 \mathrm{~km} / \mathrm{h}$ speed limit

Figure 4 - Plots of average speed values with standard deviation

Table 2 - Speed data parameters observed on roads with SSC

\begin{tabular}{||c|c|c|c|c|c|c|c||}
\hline $\begin{array}{c}\text { Road } \\
\text { section }\end{array}$ & $\begin{array}{c}\text { Length of the } \\
\text { section }[\mathrm{m}]\end{array}$ & $\begin{array}{c}\text { Speed limit } \\
{[\mathrm{km} / \mathrm{h}]}\end{array}$ & $\begin{array}{c}\text { Average speed } \\
V_{a v g}[\mathrm{~km} / \mathrm{h}]\end{array}$ & $\begin{array}{c}85^{\text {th }} \text { percentile } \\
\text { V85 }[\mathrm{km} / \mathrm{h}]\end{array}$ & $\begin{array}{c}15^{\text {th }} \text { percentile } \\
{[\mathrm{km} / \mathrm{h}]}\end{array}$ & $P_{s p}[\%]$ & SD \\
\hline \hline ASSC_1 & 2,900 & 90 & 73.7 & 79.4 & 68.4 & 0.4 & 5.4 \\
\hline ASSC_2 & 3,840 & 90 & 75.7 & 81.2 & 70.5 & 1.1 & 6.0 \\
\hline ASSC_3 & 2,650 & 90 & 75.1 & 82.0 & 68.7 & 2.8 & 7.0 \\
\hline ASSC_4 & 1,800 & 50 & 51.8 & 58.2 & 46.3 & 52.9 & 7.2 \\
\hline ASSC_5 & 2,160 & 50 & 47.4 & 50.9 & 43.8 & 13.3 & 4.5 \\
\hline ASSC_6 & 1,390 & 50 & 49.7 & 53.5 & 46.0 & 27.5 & 4.3 \\
\hline ASSC_7 & 3,420 & 50 & 50.0 & 53.8 & 46.2 & 23.8 & 4.0 \\
\hline ASSC_8 & 1,390 & 50 & 50.5 & 55.5 & 45.7 & 43.0 & 5.6 \\
\hline
\end{tabular}


almost 30\% higher than the highest $\mathrm{SH}$ value calculated for rural sections $\left(S_{H}=17.7 \%\right.$, ASSC_3), but remain on a lower level compared to reference roads.

Figures 5 and 6 present values of average speeds separated into a single investigated section (Figure 5a) and aggregated due to speed limit and the presence

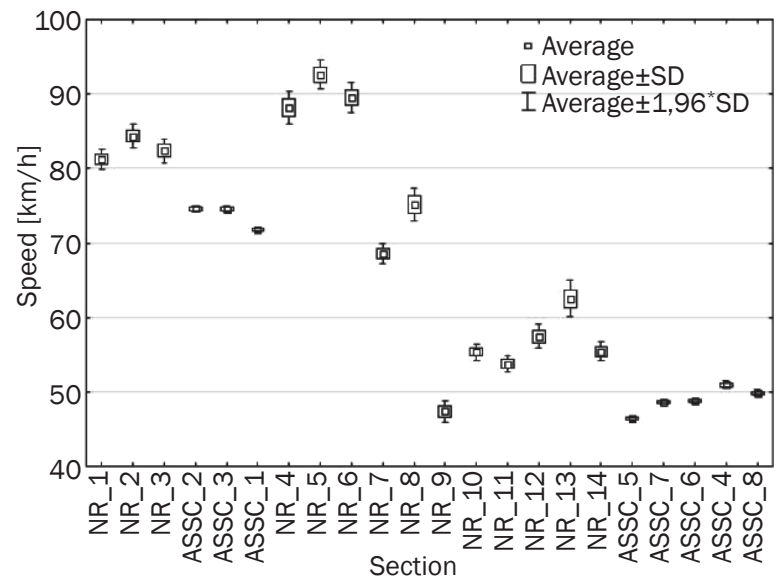

a) or lack of the section speed control system (Figure $5 b$ ). Values presented in Figure 6 show the difference in average speeds depending on the speed limit and the presence of the speed control system and hence the effectiveness of the system itself. The analysis of variance has confirmed the essential influence of the

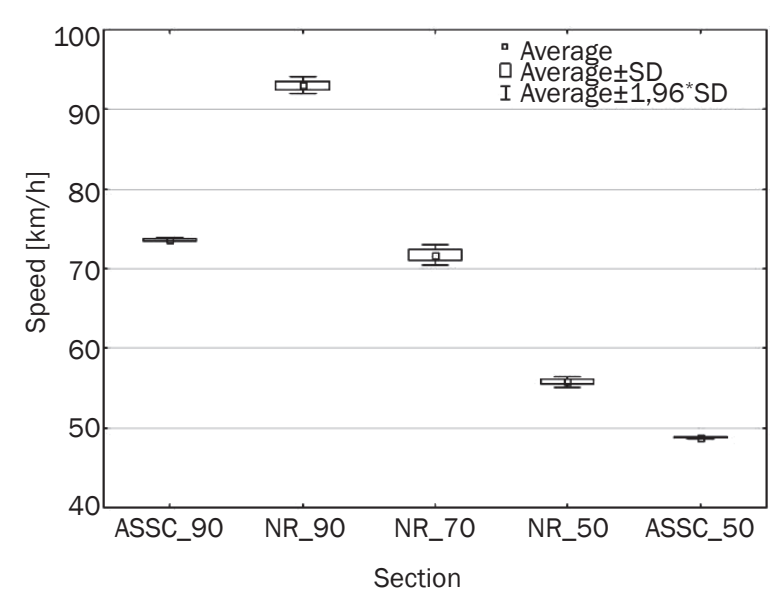

b)

Figure 5 - Plots of average speeds: a) on each of the tested sections, b) aggregated values depending on the speed limit

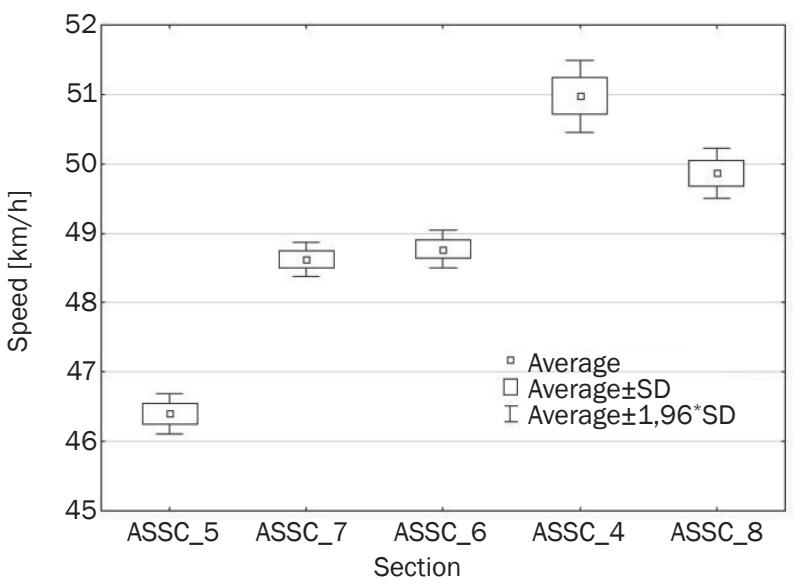

a)

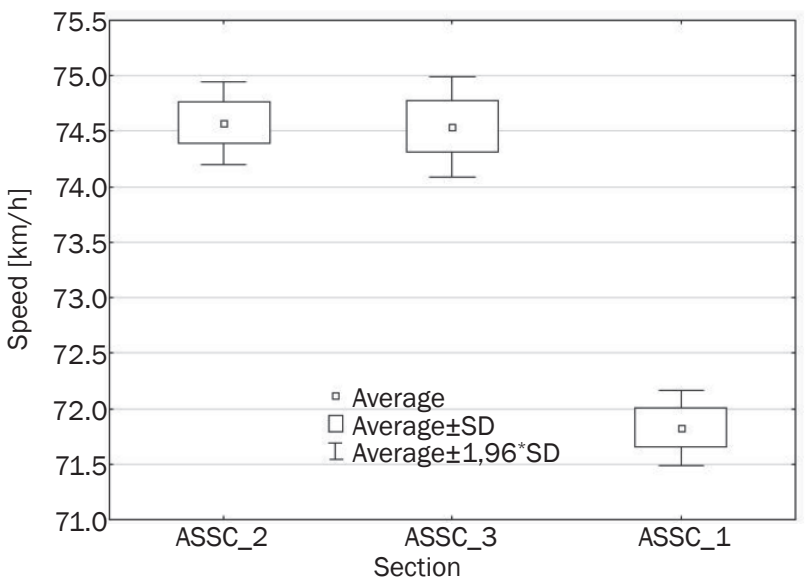

c)

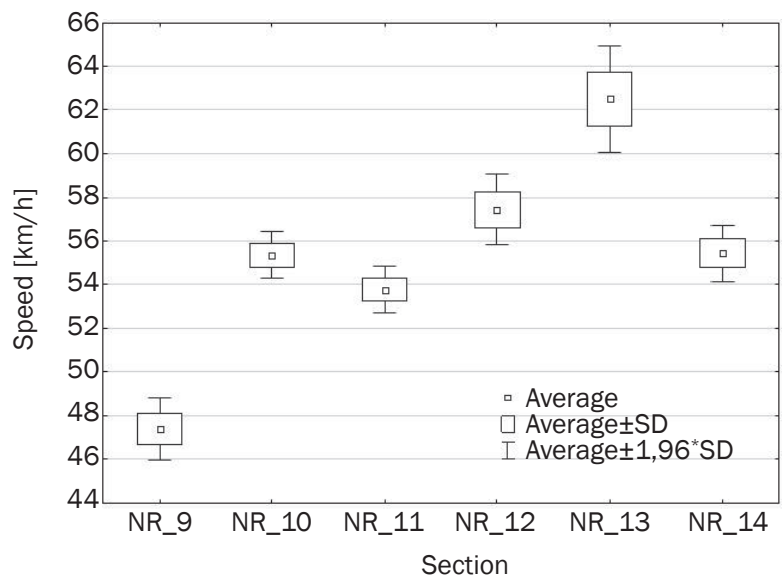

b)

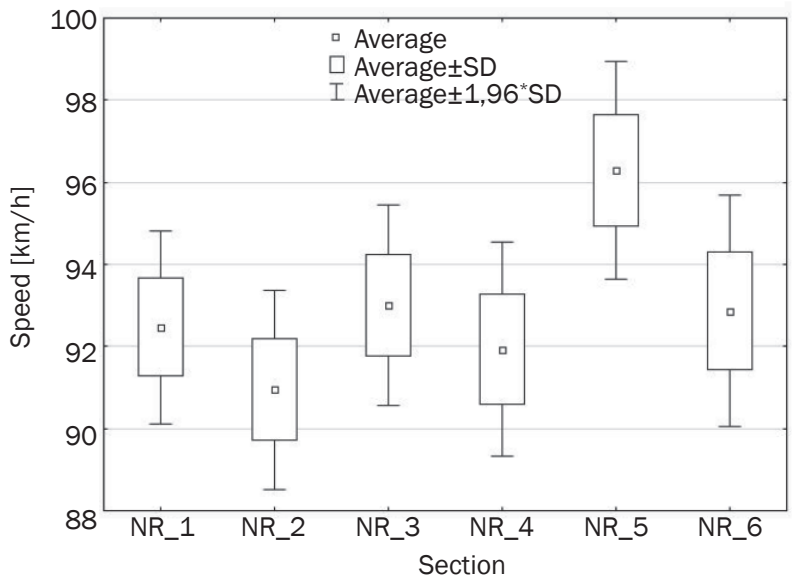

d)

Figure 6 - Plots of average speeds: a) ASSC sections with speed limit of $50 \mathrm{~km} / \mathrm{h}, \mathrm{b}$ ) referenced sections with speed limit of $50 \mathrm{~km} / \mathrm{h}, \mathrm{c})$ ASSC sections with speed limit of $90 \mathrm{~km} / \mathrm{h}$, referenced sections with speed limit of $90 \mathrm{~km} / \mathrm{h}$ 
system on the average travel speed on the controlled sections. Average speeds on ASSC sections are statistically significantly lower than speeds on the referenced roads ( $p=.0000)$. The average speed on sections ASSC_1 $\div$ ASCC_3 $\left(V_{\text {avg }}=74.8 \mathrm{~km} / \mathrm{h}\right)$ is $13.4 \%$ lower than average speed on reference sections NR_1 $\div$ NR_6 $\left(V_{\text {avg }}=86.4 \mathrm{~km} / \mathrm{h}\right)$. The effectiveness of section speed control system in built-up areas is even higher and the average speed on sections ASSC_4 $\div$ ASCC_8 ( $V_{\text {avg }}=49.9 \mathrm{~km} / \mathrm{h}$ ) is $22.6 \%$ lower than average speed on reference sections NR_9 $\div$ NR_14 $\left(V_{\text {avg }}=64.5 \mathrm{~km} / \mathrm{h}\right)$

On the other hand, the reduction of the average speeds on ASSC sections is not the only benefit arising from the presence of section speed control system.
Even though the variance analysis confirms that the difference between average speeds on ASSC sections within specific speed limit is significant, still the homogeneity of speed is improved. Firstly, it is confirmed by lower $\mathrm{SH}$ values when compared to reference sections. Secondly, Figure 7 illustrates histograms of speeds in varied conditions which reflects a positive effect of sectional speed control system in the scope of the range of individual's speeds. An explanation for that fact may be that on the sections where sectional speed control system operates, the phenomenon of calmed traffic [14] has come into being. This phenomenon is very desirable as high inconsistency in travel speed may have high influence on the safety conditions on the roads.

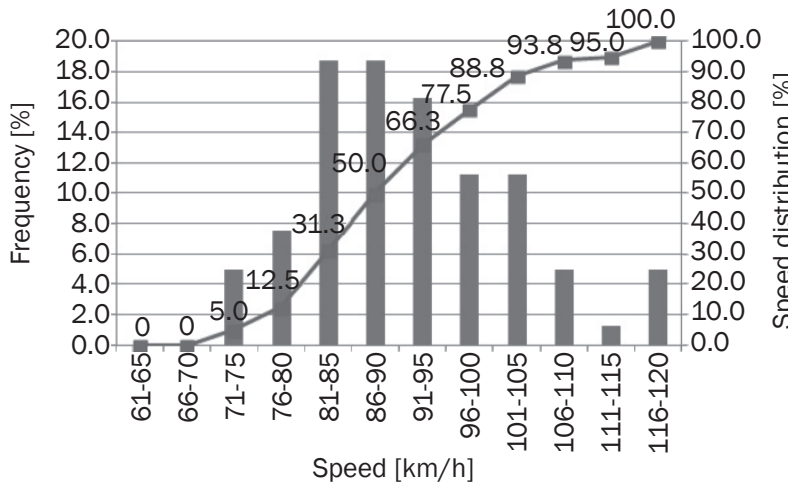

a) Road section NR_1

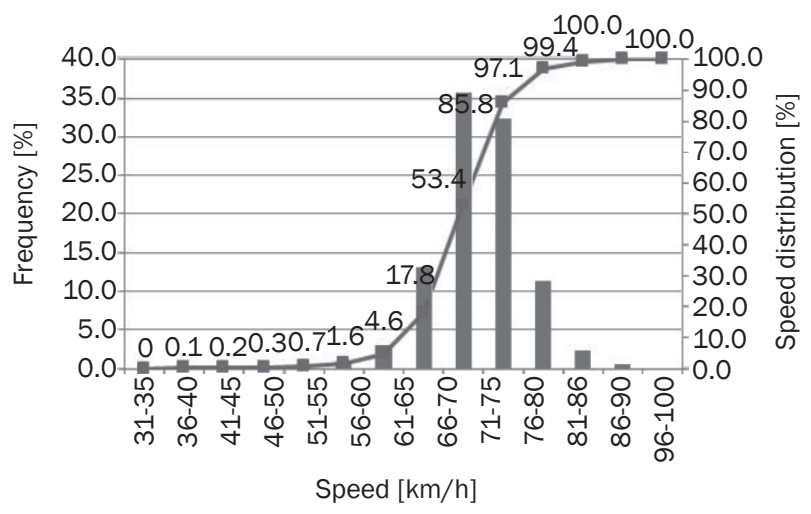

c) ASSC with $90 \mathrm{~km} / \mathrm{h}$ speed limit

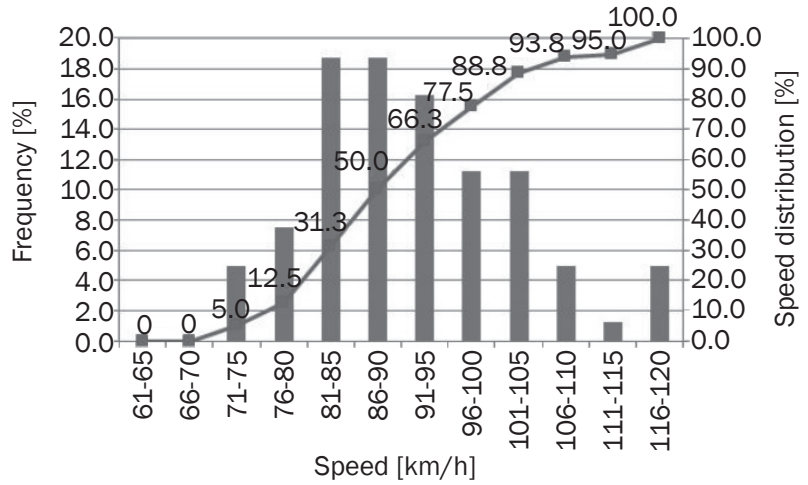

b) Road section NR_3

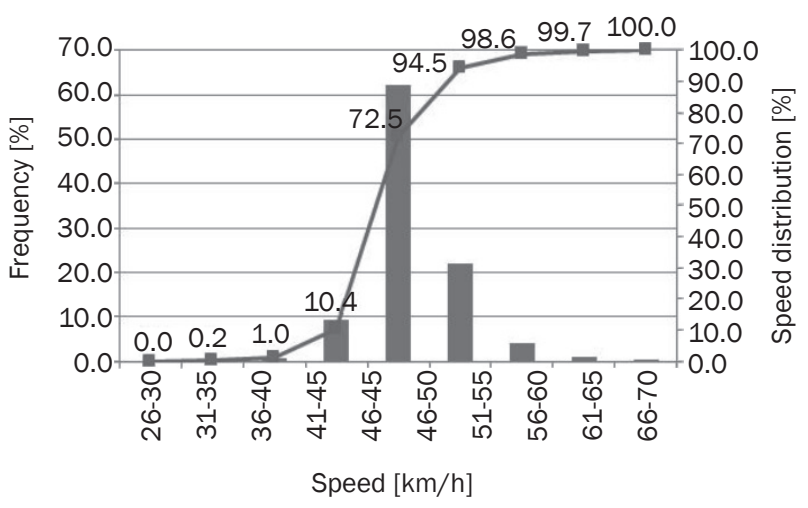

d) ASSC with $50 \mathrm{~km} / \mathrm{h}$ speed limit

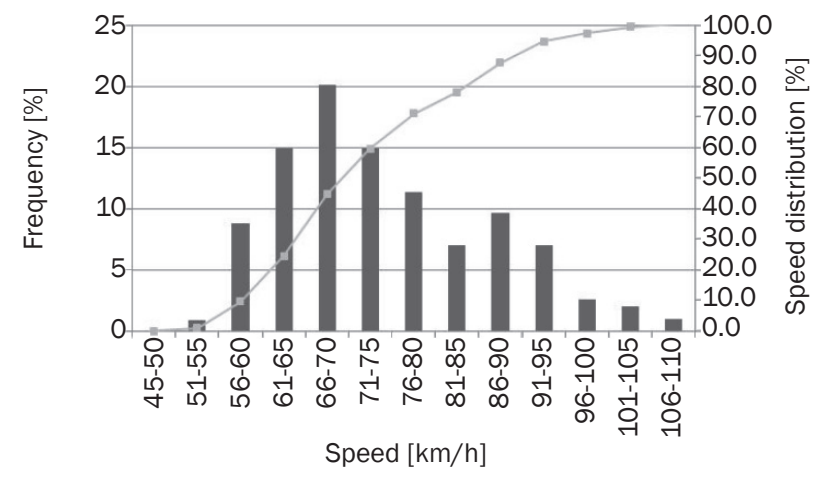

e) ASSC with $70 \mathrm{~km} / \mathrm{h}$ speed limit

Figure 7 - Histograms of speeds 
According to other research works $[15,16]$ high heterogeneity of speed may lead to unfavourable driver's behaviour and higher dynamics of manoeuvres [17, 18].

As it can be noticed from the graphs in Figure 7 , there is a distinct difference between histograms reflecting driver's travel speed on rural reference roads (Figures $7 a, 7 b$, and $7 e$ ) and roads where sectional speed control system operates (Figure $7 c$ and $7 d$ ). On reference roads the range of dominant speed (81$105 \mathrm{~km} / \mathrm{h}$ ) is much wider than the range of dominant speed $(71-80 \mathrm{~km} / \mathrm{h})$ observed on rural roads with the same speed limit but with speed control system installed (Figure 7c). Even a more narrowed range of travel speeds (46-55 km/h) can be observed on urban ASSC sections, but that can be partly explained by a lower speed limit (Figure 7d). Histogram of speeds on roads in built-up areas with $70 \mathrm{~km} / \mathrm{h}$ speed limit additionally confirms the problem of the speed dispersion on roads without section speed control. In this case speed dispersion is vastest and dominant values are within 55-95 km/h (Figure 7e).

However, even though there is a positive effect of narrowed range of dominant travel speeds, the presence of drivers travelling at a speed distinctly lower than the speed limit along controlled sections can be troublesome, especially on rural sections. In case of an ASSC section with $90 \mathrm{~km} / \mathrm{h}$ speed limit (Figure 7c) $25.3 \%$ of drivers travel at a speed lower than $70 \mathrm{~km} / \mathrm{h}$. In other drivers' opinion this is especially annoying and frustrating, and so may lead to adverse behaviour. In case of the ASSC section with $50 \mathrm{~km} / \mathrm{h}$ speed limit (Figure $7 d$ ) the number of slow drivers is distinctly lower and only $1.2 \%$ of them drive slower that $40 \mathrm{~km} / \mathrm{h}$. Possibly after drivers get used to the system and learn how to drive accordingly, this tendency should disappear or at least be flattened.

\section{CONCLUSION}

The paper presents the results of speed investigations performed on 22 sections of national roads in Poland. The investigations included 14 rural sections with legal speed limits of $90 \mathrm{~km} / \mathrm{h}, 70 \mathrm{~km} / \mathrm{h}$ and 50 $\mathrm{km} / \mathrm{h}$ and 8 sections of national roads with automatic section speed control system installed with $90 \mathrm{~km} / \mathrm{h}$ and $50 \mathrm{~km} / \mathrm{h}$ speed limits. The investigations have focused on the efficacy of the speed control system in terms of the driver's travel speed.

Conducted measurements and statistical analysis showed highly positive influence of such a system resulting in effective and significant reduction of average speeds, and the number of speeding drivers as well as improved speed uniformity. The system is more effective on roads in built-up areas with a $50 \mathrm{~km} / \mathrm{h}$ speed limit - the average speed on ASSC sections is $22.6 \%$ lower than the average speed on reference sections with the same speed limit. In terms of reduction of speeding drivers better results were observed on roads with $90 \mathrm{~km} / \mathrm{h}$ speed limit where the number of violating drivers did not exceed 3\%. Currently, the number of ASSC sections in operation is 30 across the country, but there are general plans for further development in upcoming years.

An important benefit of section speed control is that it homogenizes speed and the phenomenon of calmed traffic appears, so that it should help avoid collisions. The sections with $90 \mathrm{~km} / \mathrm{h}$ speed limit showed distinctly narrower range of dominant travel speeds in comparison to reference sections. The effect was equally positive and visible on controlled sections with $50 \mathrm{~km} / \mathrm{h}$ speed limit. The only disturbing fact remaining on sections with speed control system is the presence of much slower driving travellers as a result of speed control system installation. Such slow driving style can adversely affect faster driver's manoeuvres.

\section{ACKNOWLEDGMENTS}

The research was supported by Project No S/WBiIS/1/15 and it was financially supported by the Ministry of Science and Higher Education, Poland.

\section{Dr inż. ROBERT ZIÓŁKOWSKI}

E-mail: robert.ziolkowski@pb.edu.pl

Politechnika Białostocka

Wydział Budownictwa i Inżynierii Środowiska

ul. Wiejska 45E, 15-351 Bialystok, Polska

\section{EFEKTYWNOŚĆ FUNKCJONOWANIA SYSTEMU ODCINKOWEGO POMIARU PRĘDKOŚCI NA DROGACH KRAJOWYCH W POLSCE}

\section{STRESZCZENIE}

Prędkość jazdy jest jednym z najważniejszych czynników wpływających na bezpieczeństwo ruchu drogowego. Prędkość nie tylko wpływa na ciężkość wypadku, ale jest również związana z ryzykiem jego wystąpienia. Nadmierna prędkość odpowiada za ponad jedną trzecią wszystkich wypadków śmiertelnych rejestrowanych na drogach. W Polsce powszechny jest problem kierowców przekraczających limity prędkości dopuszczalnej. Z tego powodu skuteczne zarządzanie prędkością i egzekwowanie istniejących ograniczeń jest bardzo ważne. Rozwiązania jakie można stosować na drogach zamiejskich są bardzo ograniczone i koncentrują się głównie na wprowadzaniu administracyjnych ograniczeń prędkości oraz instalacji fotoradarów. Jednak ze względu na ich ograniczoną skuteczność wciąż poszukuje się nowych rozwiązań. Wysokie oczekiwania wiąże się z wprowadzonym ostatnio w Polsce systemem odcinkowej kontroli prędkości. Celem artykułu jest analiza skuteczności systemu odcinkowej kontroli prędkości na podstawie badań prędkości przeprowadzonych na wybranych drogach krajowych. Analizie poddano odcinki dróg na których po raz pierwszy wdrożono ten system. Przeprowadzone porównania i analizy statystyczne obejmowały podstawowe parametry prędkości takie jak: średnia prędkość jazdy, 
percentyl prędkości, liczba kierowców przekraczających prędkość oraz niejednorodność prędkości. W celu oceny skuteczności systemu przeprowadzono również pomiary prędkości na czternastu podobnych pod względem geometrii i cech funkcjonalnych odcinkach dróg krajowych zlokalizowanych w województwie podlaskim w Polsce.

\section{SŁOWA KLUCZOWE}

zarządzanie ruchem; odcinkowy pomiar prędkości; nadmierna prędkość; jednorodność prędkości;

\section{REFERENCES}

[1] Reason J. Managing the risks of organizational accidents. Routledge Tylor\&Francis Group; 2016.

[2] Elvik R. The Power model of the relationship between speed and road safety, update and new analyses. Institute of Transport Economics TOI, Oslo. TOI Report 1034/2009, 2009.

[3] Aarts L, van Schagen INLG. Driving speed and the risk of road crashes: A review. Accident Analysis and Prevention. 2006;38(2): 215-224.

[4] Kloeden CN, McLean AJ, Moore VM, Ponte G. Travelling speed and the rate of crash involvement on rural roads. Australian Transport Safety Bureau ATSB. Report No. CR 204, 2001.

[5] International Transport Forum. OECD. Speed and crash risk. Research report. International Traffic Safety Data and Analyses Group, 2018.

[6] The Polish General Police Headquarters, Traffic Department. Road accidents in Poland in 2016. Warsaw; 2017.

[7] Gaca S, Kieć M. Speed management for local and regional rural roads. $6^{\text {th }}$ Transport Research Arena TRA2016. 18 April 2016, Warsaw, Poland. Transportation Research Procedia: 4170-4179.

[8] Gaca S, Kieć M. Effectiveness of a system of automatic speed control on national roads in Poland. $15^{\text {th }}$ International Conference of Road Safety on Four Continents, 22-24 March 2010, Abu Dhabi, United Arab Emirates. 2010. p. 890-900.

[9] Jurecki RS, Jaskiewicz M. Analysis of road accidents in
Poland over the last ten years. Scientific Journal Maritime University of Szczecin. 2012;32(104)z2: 65-70.

[10] Lahrmann H, Brassoe B, Johansen J, Madsen J. Safety Impact of Average Speed Control in the UK. Journal of Transportation Technologies. 2016;6: 312-326. Available from: doi:10.4236/jtts.2016.65028 [Accessed 29th Jan 2018].

[11] Hoye A. Speed cameras, section control, and kangaroo jumps - a meta-analysis. Accident Analysis \& Prevention. 2014;73: 200-208. Available from: doi:10.1016/j. aap.2014.09.001 [Accessed 28th May 2018].

[12] Thomas L, Srinivasan R, Decina L, Staplin L. Safety Effects of Automated Speed Enforcement Programs: Critical Review of International Literature. Transportation Research Board, Transportation Research Record. 2008;2078: 117-126. Available from: doi:10.3141/2078-16 [Accessed 28th May 2018].

[13] Stefan C. Automatic Speed Enforcement in the Kaisermühler Tunnel (Vienna, A22 Motorway). Austrian Road Safety Board; 2006.

[14] Ziolkowski R. Influence of traffic calming measures on drivers' behaviour. $9^{\text {th }}$ International Conference: Environmental engineering, Vol. 4, 22-23 May 2014, Vilnius. Available from: doi:10.3846/enviro.2014.180 [Accessed 12th May 2017].

[15] Nicole N, Brandenburg S, Twisk D. Improving homogeneity by dynamic speed limit systems. Accident Analysis and Prevention. 2010;4242: 944-952. Available from: doi:10.1016/j.aap.2009.05.002

[16] Goldenbeld C, Van Schagen I. The credibility of speed limit on $80 \mathrm{~km} / \mathrm{h}$ rural roads: the effects of road and person(ality) characteristics. Accident Analysis and Prevention. 2007;39(6): 1121-1130. Available from: doi:10.1016/j.aap.2007.02.012

[17] Benes J, Pribyl O. Effects of highway management on traffic flow characteristics. Archives of Transport System Telematics. 2014;7(2): 14-18.

[18] Wahlberg A. Driver celeration behavior and the prediction of traffic accidents. International Journal of Occupational Safety and Ergonomics. 2006;12(3): 281296. Available from: doi:10.1080/10803548.2006.1 1076690 [Accessed 17th Apr 2018]. 